\title{
The Romany Voice on Interaction with the Health Care System in Sweden
}

\author{
by Margareta Popoola, Malmö University
}

\begin{abstract}
This article deals with the Roma migrant's experience when encountering the health care system in Sweden. The article takes as a point of departure research conducted in the south of Sweden between 2008 and 2010, and this research is part of a wider field which addresses the challenges for the multicultural society. The background to the study is to be found in the Roma migration to Sweden over the last decades. The aim of the study is to examine how health care is experienced from the Roma's point of view. What kind of attitudes do they meet? How are their special needs taken into consideration? Are there any special needs being neglected? The results of the study show that experiences are diverse. There are not specific needs with reference to ethnical background or cultural aspects; instead, people ask to be listened to, to be given attention and to be treated with respect.
\end{abstract}

This presentation is based on a study undertaken between the years 2008 and 2010. It focuses on the experiences Romany people have with the health care system in Sweden. The Romany community is one of the largest minority groups in Europe. However, they have faced a multitude of problems over the centuries, often caused by exclusion and discrimination. Romanies have received national minority status in several countries. Although this minority status could be considered to be a form of societal recognition, it is not a guarantee for a diminution of the problems this group suffers. The Romanies focused on in this article are not only minorities in a national context; they are also migrants or descendants of migrants. Migrants are affected by social inequalities, and they often face poverty and social exclusion that negatively influences their health (Davies et al. 2006). According to the European Council's data, Romanies suffer extensive health problems and have a shorter life expectancy than the mass population in both Eastern and Western Europe (Council of Europe 2003, p. 15). These higher mortality rates and extensive health problems also include Romanies living in Sweden (Kärfve 2000, p. 94).

The degree to which Romanies' ill-health is prevalent in Sweden is less known; however, the Swedish National Institute of Public Health's (SFHI) data on health conditions amongst national minorities indicates that there are higher instances of heart disease, physical inactivity and diets with high fat content among Romanies when compared to the majority of the national population (SFHI 2010, p. 14-15). These health conditions could be linked to the fact that Romanies live in social circumstances that lead to discrimination and exclusion from parts of society; in fact, it is well known that there is a link between exclusion and ill-health (Graham 2000; Putnam 2006, p. 344-348; SFHI 2005, p. 49; SFHI 2010; SOS 2009, p. 384). This places demands, not only on society at large, but also on the health care that has to deal with the consequences of these problems. The health care system's interaction with both Romanies and other ethnic minorities raises questions about general and culturally specific discrimination and, moreover, how this cultural discrimination should be handled. Do Romanies have a need for culturally competent staff? If so, is the need for that special solution limited only to this ethnic group? In this study, Romanies with experience of different health care situations have been used as the starting point to try to establish a picture of their relationship with the health care system and ascertain their confidence in it.

The starting point for this essay is the study's result, which is based on interviews with Romanies, and gives an insight to how health care is experienced from a minority perspective. Questions discussed 
include accessibility, cultural competence, and special solutions derived from culturally specific needs. As experience forms the basis for one's attitude, Romanies were asked about their previous experiences with the health care organisation's staff (as it could be said that it is the staff that form the foundation of trust, or the lack of it, in this welfare institution). The study is not about measurable or objective knowledge; instead, it should be seen as an attempt to highlight the voices of individuals and disclose the idea of a mutual overall picture. Although Romanies have shared mutual experiences, they do have differing opinions. This places demands on the health care system to meet Romanies' requests that arise in specific situations.

\section{Who, How, What?}

In every context of research, it is important that the reader knows in what way the research was carried out, who has been interviewed and what questions they were asked. Without delving into the methodological aspects, it is useful to present certain background facts.

The delimitations for this study were Romany men and women aged 18 to 65 , living in Southern Sweden, who are either first- or second-generation immigrants and who have had experiences (either directly or through a close relation) with the health care system in Sweden. It should be noted that access to the participants has not been gained through any communication with medical staff, medical journals or any other public information that could reveal the participants' identities. All participants have been approached outside of the health care system's sphere through various means: through educational efforts where one of the target groups are Romany; through contacts who, in various ways, work with Romanies as a group; and through contact with individual Romanies who, by way of the snowball method, have used a network of close family members to communicate their experiences.

The interviewees belong to the larger Romany groups originating in Poland, the Czech Republic, Slovakia, Hungary, Serbia, Kosovo, Macedonia, Bosnia, Turkey, Germany, Italy and Finland. They belong to different groups, such as Lovara, Bergitka, Arli, Kalé, and their religious belongings are to be found in Christianity as well as Islam. In other words, they represent a wide spectrum of different belongings in both ethnical and religious aspects. Individual and group interviews, conducted in Swedish, have taken place with twenty eight people (twelve men and sixteen women), with translation only required in a few cases. Further, three group interviews were conducted that focused purely on the need for special solutions and the possible need for the education of health care professionals in Romany culture and lifestyle. These latter group interviews included twenty people (twelve men and eight women). Additional information was obtained through seventy-four questionnaires, out of which twenty eight were completed by the above interviewees, and the rest by respondents not included in the groups above. In total, this study has included opinions from ninety-four persons (fortythree men and fifty-one women). To clarify the framework for the study, it should be pointed out that health care professionals were not asked for their opinions on the questions in focus. However, among the interviewees, some individuals did have experience of the health care system as professionals. It shows there aren't streamlined categories of Swedish care providers or migrant care recipients.

\section{Trust and Recognition}

Trust and recognition are two terms (or concepts) used in this article to explain the interactions between patients, specifically from minority groups, and staff within the health care system. Of course the staff can also belong to a minority group, but they principally represent the health care system as an organisation. The health care system is regarded as a welfare institution on which both majority, as well as minority, members of society can depend. Furthermore, there is an assumption that dependency is built on vulnerability, which requires trust in the health care system as an abstract phenomenon. Another assumption is that individuals have a need for recognition of their persona, their ways and how they experience themselves, but how can one understand trust and recognition 


\section{as abstract concepts?}

Trust and recognition, each on their own, have different meanings; however, when combined they create a framework for understanding how individuals relate to one another. Trust has a multitude of alternative synonyms such as confidence, faith and reliance, and all of these expressions mirror some form of hope in someone or something. This creates a positive value, although hope is not always necessarily functional. Neither hope nor faith develops in a social vacuum; they are presuppositions that are built on the mutual understanding of present and past time. In short, it is one frame of reference built out of another. It should be noted that recognition in a legal sense concerns a person acknowledging something unfavourable about his or her own persona; however, it is not this form of recognition that this article refers to. In this instance, recognition is about a general claim for confirmation (Heidegren 2009).

Both George Herbert Mead (1863-1931) and Erving Goffman (1922-1982) have contributed to the discussion about recognition in a psychological social perspective. Although their work does not focus on the concept of recognition, their work on identity and its construction highlights confirmation, among other reactions, as leading to positive self image and other types of stigmatisation (Mead 1976; Goffman 1972, 2000). Goffman, who devoted his career to trying to document how direct interaction between people develops on a micro level, discusses close-lying concepts such as respect, esteem and denigration, and their counterparts - which could be seen as either recognition or a lack of it (Taylor 1994; Fraser 2003). A lack of recognition could be based on mistrust, which conversely means that trust is built on recognition. Trust and recognition can occur in the interaction between individuals, between groups or between general societal institutions. However, paradoxically, trust in societal institutions is sprung from the notion of solidarity, even though solidarity itself is not based on trust but on mistrust of people who are different and belong to another group (compare: Ramirez 2001, p. 139). Solidarity as a concept can be most useful in understanding both trust and recognition in their wider context. Richard Rorty (1992) points out that people are selective when deciding which characters are to be emphasized in different situations. According to Rorty, solidarity is developed through relations between individuals and groups. The outcomes of the relations decide who will be considered as a part of the community or not. When differences are linked to people who are branded as belonging to a group outside of your own, there is a risk that differences are explained as being group contingent, or merely cultural, rather than a result of individual differences.

\section{What is Culture and Cultural Competence?}

A simple search on Google on the phrase 'cultural competence' produces more than 5,000,000 hits, which gives an indication of the concept's timeliness. Furthermore, there are links to concepts like multiculture, cultural pluralism and cultural diversity. During the last decade, diversity has evolved into a concept that encompasses all forms of differences. Regarding cultural differences questions about what culture is, and how it can be understood, arise. These questions are impossible to answer in a straightforward manner; however, it is possible to make two rough distinctions: one qualitative and one social scientific. The qualitative consists of dance, music, handicrafts and other artistic expressions, while the social distinction has a broader significance, consisting of all human activity (Illman and Nynäs 2005, p. 28). The difficulties with grasping what a culture is were demonstrated in an interview with a young Romany who explained that Roma culture 'is everything from offering a cup of coffee to a visitor, to looking after your elderly and your children' (Popoola and Söderman 2010, p. 72, p. 122). The young Romany then continued with a firm speech about Romany solidarity. He declared that Romanies always help other Romanies, whether it concerns food and lodging or lending money (Popoola and Söderman 2010, p. 122). This statement demonstrates the existence of ideals that emphasise group solidarity. Different types of ideals, interlinked with the assumption that these standards are significant for one group but not for others, function as cultural boundaries in the wider society. When talking about society as a culture, we are using an agricultural metaphor to guide 
our attention to very specific aspects of social development (Morgan 1997, p. 120). However, there are various ways of understanding culture. In an article published more than fifty years ago, different definitions of culture were calculated to a number of at least 160 (Dunbar 2006, p. 171). Culture as a concept has had various meanings during different epochs of history, but is nowadays merely used to signify that different groups of people have different ways of living (Morgan 1997, p 120). Consequently, culture and ethnicity can be perceived as exchangeable entities. Some people would disagree and point out that an ethnic group is not a culture in itself; people belonging to the group have a common culture, which means they share beliefs, values, language and traditions. Culture refers to the way a society is organised, and ethnicity refers to shared meanings derived from values and norms in practice. This way of argumentation shows how difficult it is to isolate questions about culture from ethnicity and society in a wider context.

I will not try to make a full review of all the different ways of understanding culture during the past centuries, but a few perspectives should be pointed out. With a point of departure in the twentieth century, scientists tried to understand the stance of organisations and different societies. Geert Hofstede, one of the researchers in the field of organisations, is particularly important. Hofstede (2001) has tried to map the culture of nations by collecting data from multiple organisations around the world with reference to variables that are seen as objective. According to Hofstede, 'mental programs' are developed in childhood and reinforced through educational programmes and organisations later in life. According to Illman and Nynäs (2005), this view of culture is the collective programming of human beings, which conveys a deterministic approach to culture in practice (p. 31). In all discussions about culture and ethnicity, there seems to be a drift between the general and the specific, and the mutual and the distinctive; both of them unite and distance populations from one another. Hofstede's attempts to find the core for different groups of people are surely valuable, but there is a risk of over-generalising what are understood as norms and values in certain contexts. It should not be underestimated that culture is an ongoing process.

Linda Lill (2007), who has studied elderly care in Sweden, shows how ethnicity 'is a product of social interaction rather than a pre-defined role or mode of being' (p. 229). In meetings, people have different conceptions of each other's identities, and from these positions caregivers, sometimes unwittingly, use ethnicity as a marker for their construction of care (Lill 2007, p. 229). It is of no interest whether differences actually exist. Statements, stereotyping and self-image represent examples of culture's dilemma as it tries to capture shared differences within communities. Lill's perspective is in line with a constructional approach where culture merely is a designation of people's attitudes, behaviour and activities in constant change (compare Bauman 1999, 2008; Jenkins 2008). These changes have an impact on a wider society, just as society (or the overarching structures) has an impact on individuals (Giddens 1997).

Giddens (1997) highlights flexibility, which is a need for individuals to constantly incorporate changes that have an impact on daily life and personal identity. With this approach, flexibility turns out to be a part of cultural life in contemporary Western societies. Even when culture is discussed as a distinct phenomenon, reflexivity seems to be a concept to relate to. Sometimes flexibility can be expanded in a way that makes it difficult to recognise how one culture is differentiated from another. In this case, culture should be analysed from both an individual level and from a collective level. At a collective level values and norms can be carried out and can provide meaning for individuals, which does not stop a person at an individual level acting flexibly according to the goals of a given benefit. Its perspective emanates from theories of Rational Choice, which is grounded in an economic view. People make their choices from an economic calculation of costs and benefits that will be found in the field of economy (Outhwaite and Bottomore 1994, p. 543). This latter way to understand human beings and their actions actually needs to ignore certain cultural aspects in favour of individual approaches in order to understand people's motives, beliefs and desires. How do we understand ourselves and the 
world we live in?

Working with cultural difference is about being able to adapt to different situations and contexts, that is, everything that is normally included in the concept of 'social competence'. There is no precise definition of 'social competence', but it is usually understood as a person's ability to interrelate with other people, to have a capacity to blend into different situations and to cooperate with people in a mitigating manner. This way of dealing with the concept of cultural competence is principally about interpersonal relations. It accepts that differences can originate from people's ethnic or cultural backgrounds, but it gives these factors less significance; instead, it highlights factors like power, dependency or other circumstances. This method of studying interactions within the health care system is most typical of research in the United Kingdom and New Zealand (Björk Brämberg 2008, p. 25). In Sweden, cultural competence has mainly focused on interaction between the mass population and immigrants or minority groups. Influence has come from the Unites States (Björk Brämberg 2008, p. 25), where concepts like cultural pluralism have increasingly been replaced with diversity. Although diversity has a wider meaning, there has always been a tendency in Sweden to use different ethnical backgrounds as a way to measure diversity (compare: Schölin 2007). When organisations are trying to accomplish diversity ethnicity becomes an essential issue. With this approach, ethnicity becomes a competency in itself. This way of interpreting cultural competency means that immigrants or members of a minority group are expected to have a special competency when meeting patients, clients or customers with the same ethnic background. In this debate, Linda Lill (2007, p.208) contributed by suggesting that staff with special skills in languages used by migrant caretakers could be employed with this criteria in the contract of employment. Despite her own suggestions in the field, Lill warns for the consequences of segregation as a result of separate solutions (Lill 2007, p. 208). The existing research in this field demonstrates an ambiguity towards the necessity, or even desirability, of extensive knowledge about caretakers' special cultural background. Cultural competence can, aside from language skills, also be interpreted as knowledge about different groups' traditions, beliefs and values; even so, there are varying opinions about what underlying knowledge of which cultural factors is needed to best meet the needs of immigrants and minority groups. Masoud Kamali (2002, p. 51-55) warns for a development where ethnicity becomes a competence in itself. If members of a minority group are expected to have a special competence when meeting patients, clients, or customers with the same ethnic background, the risk is that people will be reduced to their culture. A response to this argumentation could be that if culture is to be ignored, all kind of differences between people can be explained as individual differences. Both ways are kinds of cultural reductionism (compare: IIIman and Nynäs 2005, p. 30). One way to combine these two points of view could be to elaborate on culture and sensitivity to individual preferences in a less dogmatic way. Cultural sensitivity could simply be a way to obtain and have knowledge without it being stipulated as in a manual. Experiences from working with minorities in Australia show that 'it is important that even the professionals have to be aware of the sort of community they are dealing with' (Roe in Purdie et al. 2010, p. 248). What does it mean to be aware of the community one is dealing with? With respect to community and the competency to navigate within it, culture cannot be ignored. Hays' (2008) definition of cultural competency is to have 'self-awareness of values and biases, understanding client worldviews, and intervening in culturally appropriate manner. Cultural competency is a set of congruent behaviours, attitudes and policies that come together in a system, agency or among professionals and enables the system, agency or professional to work effectively in cross cultural settings' (Drew et al. in Purdie et al. 2010, p. 198). According to this definition, the professionals should be aware of values and worldviews existing in the minority group; however, this does not mean that the individual preferences should be ignored. Moreover, researchers like Lill and Kamali do not object to extensive knowledge about other cultures; the question is to what extent this knowledge should be given significance in differing circumstances. For example, is the need for cultural competency valid within the health care system? 


\section{Cultural Competence within the Health Care System}

Elisabeth Björk Brämberg (2008) has studied cultural competence within the health care system; in her dissertation about nursing she investigates immigrants' experiences as patients in Sweden. Björk Brämberg asserts that cultural competence is of lesser importance for good health care and thereby contradicts suggestions by Leininger and McFarland (2006). They argue that health care professionals should have a working knowledge of cultural characteristics. Their suggestions are built on the 'Culture Care Theory' founded in the 1950 s by Madeleine Leininger. Leininger combined her interests in social anthropology and nursing issues, and became one of the first to consider cultural aspects outside of those normally considered by a western population (Leininger and McFarland 2006). Her interest in care, social anthropology and the need for medical efforts outside of the United States has resulted in a holistic ambition and a number of factors that she recommends to be considered within trans-cultural care. These recommendations are based on a model about how one should work and which factors need special knowledge and insight. The cultural and structural factors she highlights include religion and philosophical issues, kinship, political and legal factors, cultural presuppositions, and values linked to class and gender (Leininger and McFarland 2006, p. 14, p. 18-19).

Leininger argues that when interacting with a patient with a different cultural background there is a need for the health care staff to have knowledge about various elements of the patient's culture. Armed with this cultural background information, the caregiver is expected to work holistically with the patient, their (ill-)health, diseases and life situation. This goal of understanding cultural frames of reference outside of your own can be considered sympathetic and innovative; however, there is a risk that knowledge and understanding can devolve into contra-productive generalisations. This risk is imminent if knowledge is based on fragmented information, and it could instigate an instrumental understanding. Staff might have knowledge about differences in traditional and religious expressions, but lack nuances of individual differences and contexts; for example, although generally Muslim people do not wish to eat pork, it does not necessarily mean that all Muslims adhere to this. Conversely, understanding that some Muslims actually do eat, and enjoy, pork sausages does not mean that all food restrictions are meaningless. There may also be exceptions, such as special circumstances and deviations from a life philosophy, which are not included in an assertive view of cultural differences.

It is, perhaps, more important to ask questions and set the cultural differences aside. Do patients need the staff of societal institutions to have knowledge about factors that are not directly related to their concerns? Does a patient with a fractured femur need to be treated by staff with a working knowledge of his or her customs and traditions? The illness and treatment are most likely to be the patient's immediate interest, while culturally-specific issues concerning festivities or everyday life are likely to be of lesser importance. However, experience and insight into underlying cultural factors could be essential in a vulnerable situation and, in that case, it is interesting to find out if the Romany people believe that they are in need of Romany-competent staff that have knowledge about their culture.

\section{General or Specific Needs?}

The results from this study seem to support Björk Brämberg's (2008) assertion that cultural competency is of little significance. The Romanies included in this study did not seem to wish for either special solutions or for greater knowledge of Romany culture amongst health care staff. Furthermore, the questionnaires did not support the need for culturally-specific efforts aimed at Romany groups. Other information could contradict this claim, for example the discussion of issues of diet and its differences in relation to tradition and religion. There are voices highlighting ritual laws of cleanliness while others point to a divide between the masculine and the feminine. This involves dividing the body into upper and lower regions, and the disgrace in discussing taboo subjects like sexuality, bodily fluids, or other subjects related to bodily functions. In this case, there is a warning against mixing men and women. Other people point out the difficulty of having doctors and patients of different sex. 
However, there are also accounts of how coercion (or perceived coercion), necessity, and habit have changed attitudes. A young Romany woman with a health care education compares her own attitude with that of the older generation:

I don't think the young care so much. In the beginning, when there was a male doctor at the women's clinic I cared, but now I don't. You kind of have to get on with it. The first time I went to the gynaecologist he was male. I felt [awful] and thought, is he going to [examine me]? But then after, it didn't matter. But my grandmother! Women in their middle ages and up should get a female when they want it, but I haven't heard if they can choose themselves. My grandmother would rather have died - she would want a female.

According to this woman, the division is between the young and the old, and between habit and necessity; hence, this could be the gateway to understanding the disparate opinions that have emerged concerning gender related issues. However, when it comes to the care of the elderly, the sick or others in need of care, the interviewees disagree: 'I would never allow our elderly to be alone' and 'it is a disgrace for Romanies. We are of the opinion that it is us who should care for our elderly.' While these comments reveal views on set norms, none of the interviewees themselves belong to the category of elderly in need of care. One of the female interviewees discusses the difficulties with working full time and having to care for her parents in the future; in other words, it would not be her first choice to give up work and become a caretaker for her family. Another interviewee whose mother has had a recurring need for care stated, 'My mother has now become so fed up with everything that she has requested to be put up in a retirement home.' Even if there is a general consensus about wanting to care for the elderly within your own family, these contrasting opinions clearly show that individual differences exist within the Romanies as a group. Consequently, the Romanies hold many different points of view but, in one respect, there seems to be a great consensus: they do not want to be favoured or discriminated against, they simply want equal care. It could be argued that equal care is care on the conditions of the majority (Fonseca and Malheiros 2005, p. 90). However, the issue of minority has been recognized in the Care and Healthcare Law's motto, which states that everybody has the right to good health and equal care irrespective of nationality, gender, income or status (SFS 1982, p.763). How do these rights work when applied to Romanies as a distinct national ethnic minority?

\section{Accessibility}

To be able to access care and to be provided with the right care at the right time, a number of factors need to be met. One such factor is the proximity of health care; however there also need to be ways into the health care system. Patients are directed to telephone contacts or care facility visiting hours, and from there redirected into the system. From the patient's perspective, telephone contact does not always work, and sometimes even visiting a care facility is not an adequate means by which to access care. One man says:

I experienced a situation when I was at the health care centre. I was in the waiting room when a 52, 53 year old man entered, and he started screaming at them because he had phoned several times. He couldn't speak Swedish, so he went to the reception and started speaking Hungarian. Since I speak Hungarian myself, I went over to try to help. He had to come down there because he had phoned but couldn't speak enough Swedish, and they had hung up on him three to four times.

In this example, the irritation was caused by language difficulties, which could not be dealt with on the phone or even by visiting the health care centre. The situation was solved because there happened to be a person in the waiting room who spoke the same language as the man seeking care. The general critique against the health care system concerns inaccessibility, and telephone contact is highlighted as an especially problematic issue. It is difficult to get through in a phone queue that often results in an answering machine taking your call. "Please hold" is hardly an answer a person in need of care 
wants to hear. Difficulties with establishing contact with the health care and getting treatment when problems are current (and sometimes acute) are, admittedly, not just something that affects Romanies, immigrants and minorities; however, this inaccessibility can have different outcomes depending on your ability (or relatives' and friends' abilities) to communicate your problems. Despite Romanies and the general population sharing similar problems with the health care system's inaccessibility, it affects them differently.

\section{Attendance or Gathering?}

It has been established above by the Romanies interviewed that there is no general wish for either special solutions or greater background knowledge about Romany culture amongst health care staff. These results should not be interpreted categorically; however, even when there are individual differences, there is always a predominant point of view. It is constantly pointed out that in Romany culture it is common that a serious health condition leads to a larger attendance of family, friends and close relations.

I can only speak for my own group, but I can say that we believe strongly that one should not leave this life alone. That's very important. But sure, I can also understand that there are other sick people too. (Female interviewee)

When does a group of people change from being a group into being a collective? The interviewee above laughs when she says, 'in some cases it is enough to be four people.'

Before, they [the staff] got sort of scared, which I can understand. They have learned though that whenever a Romany person is in hospital there will be a lot of visitors. Then a guard normally comes by to check that everything is ok and calm. This is how we show our gratitude [to our loved ones]. Even though I might be in the middle of a quarrel with him; if he's in the hospital, I will turn up. (Male interviewee)

Large visitations require both physical space as well as an understanding of the Romanies' need for these gatherings. The background to them can be explained in terms of respect and care, but also guilt and shame. There is respect for the family and care for the sick, but also insurance to avoid the guilt and shame of neglecting your relatives and friends. A deeper understanding is based on knowledge of the complexity of underlying cultural expressions, and helps to recognise the minority's needs. Whether this recognition will lead to the design of special solutions is another issue.

\section{The Complexity of Discrimination}

In all discussions concerning minorities, there is always a risk that individuals are mainly projected as carrying culture. Specifics emerge at the expense of generalisation, and human dimensions take a back seat through the beholder's effort to try to understand the differences. It is a way to simplify, with a risk of disfavouring individuals.

One should note that some forms of discrimination are not necessarily negative. The concept can be considered objectively, and the behaviourists used as an example. They worked both with generalisation as well as discrimination, and the latter mostly deals with the ability to distinguish what are considered to be irrelevant signals (Madsen 1970, p. 39; Smith 1993, p. 265-266). Generalisation and discrimination in collaboration lay a foundation for categorisation (Madsen 1970, p. 39). On a social psychological level, both generalisation and separation are necessary in order to categorise and to orient yourself in the world. In this sense, we all discriminate as we categorise according to our experiences in an attempt to consolidate our situation (Berkowitz 1974, p. 156-157; Douglas 2004, p. 47-62). Even if you should consider this type of discrimination objectively, it does not mean that all forms of discrimination are free of objection. One could easily claim that categories in themselves (skin colour, national origin or other distinctive attributes) lay the foundation for everyday discrimination. 
In the United Nations' Convention on Human Rights (1966) and the European Council's Convention on Human Rights (1950), discrimination, as unfair treatment, is contrasted with humanity's right to the same basic rights (Roth 2008, p. 9-10). By using these starting points, the ban against discrimination is defined within legislation (SFS 2008, p. 567). Consequently, discrimination can be seen objectively as distinctive, but every distinction based on ethnicity, gender or special attributes used to degrade a person must, therefore, be considered an expression of negativity.

There are a multitude of terms encompassing different forms of discrimination, such as structural discrimination, statistic discrimination, institutional discrimination, and direct or indirect discrimination. In this article, only experienced objective and experienced subjective discrimination are discussed. These concepts both complement and exclude each other depending on the situation and context. Objective discrimination is the distinction of people receiving different treatment, almost living by separate rule-systems. Subjectively experienced discrimination arises when a person feels that they have been wronged; however, this does not necessarily have parallels in objectively measurable discrimination. A person can have the same rights as everybody else but still feel excluded, and while this feeling is not necessarily provable, it is there nonetheless.

With the risk of generalising, I would claim that both forms of discrimination have haunted Romanies throughout the centuries. How can discrimination be understood in an up-to-date context, with health care as the arena and Romanies as the target group?

There are many Romany testimonies about the discrimination they experience when using the health care system. There are accounts of conflicts in waiting rooms, testimonies of doctors making summary diagnoses and accounts of Romanies feeling belittled and disrespectfully treated. There could be explanations, as the other sides to these stories have not been told, but irrespectively, Romanies unanimously voice experiences of being dissociated by the people around them. It is not a measurable exclusion whose negativity can be proved; nonetheless, Romanies claim to feel, and experience, discrimination as a concrete expression of disinclination towards them. How can you feel discriminated against when there are no verifiable mechanisms of exclusion?

\section{The Face Shows What You Think}

There is extensive research into people's postures, facial expressions and ways to subtly send messages. Non-verbal communication patterns fascinate people, and there have been varying theories on whether facial expressions are culturally specific or independent of upbringing or origin. Charles Darwin (1809-1882) is one such scientist who spent time trying to understand both human and animal emotional expressions. He argued that the facial expressions that reflect emotions, such as shyness and disgrace, are universal and independent of culture (Fast 1970, p. 19; Scheff 1994, p. 80). However, Darwin's assertion has been questioned by those who claim that there are no congenital and consistent patterns that reflect given emotions (Fast 1970, p. 9). With the support of this critique, it is possible to argue that facial expressions are culturally specific (as is the way we interpret them) which does not mean that there are clearly distinguishable facial expressions within or between different ethnic groups. According to research, the differences between anger and fear are hard to interpret (MacAndrew 1986; Blais et al. 2008), and it should be noted that anger is one of several possible consequences caused by fear. Whether or not this is a universal truth, there are many correlating emotions and facial expressions that can be observed around the world (Mehrabian 2007). Psychologists Wallace Friesen and Paul Ekman have worked on trying to increase knowledge on the matter, and their findings partly prove Darwin to be correct. Their research, from different parts of the world, together with Sorenson and Tomkins' research, shows that people, partly, identify the same emotions (Friesen and Ekman from Fast 1970, p. 19; Gladwell 2006, p. 172-186). They studied facial muscles to try to understand how facial expressions should be interpreted, and their research was devoted to the general (what can be observed independent of ethnical or cultural background). Their 
theory is that the face is a source of information, which reveals what a person is feeling at a particular moment (Friesen and Ekman from Gladwell 2006, p. 172-186). Ekman believes that the information that can be read from looking at a person's face not only signals what the person is thinking, but also, to some extent, actually is what the person is thinking about (Gladwell 2006, p. 172-186).

This reasoning makes no distinction between humans and thought; in other words, a person changes personality in relation to how their thoughts change. A deprecation built on prejudice sends signals to the receiver who, in turn, will answer these signals. During this process, to an experienced person, the face is as revealing as an open book; together with gestures and posture, it can provide enough information to determine whether a person has a dismissive attitude or not. One Romany woman expressed it like this: 'We got a room, and they did everything exactly as they were supposed to. It wasn't that we didn't get care, absolutely not,' but she still felt that they were firm and dismissive.

\section{Psychological Defence}

The experience of discrimination can lead to a psychological defence consisting of a multitude of strategies. One strategy is to simply try to avoid appearing to be Romany, to hide one's ethnicity, or, as Erving Goffman (1972) calls it, 'passing'. A female interviewee tries to explain how she avoids drawing attention to her Romany ethnicity, and suggests that she can escape negative treatment this way:

I have to say that I think I am much spared. Partly because I have looks that people generally think are Turkish or maybe Chilean or something ... I can almost say that if they had known I was Romany (because it has happened to me many times), then I would have bad experiences. I know others who have had.....

Do you feel the difference when you are dressed in Romany clothes?

Oh yes, it's a huge difference. I have never sought medical help wearing those clothes, I never would ..... No, no, if I wear my Romany clothes, I get worse service no matter what it concerns.

Another strategy is acting out. A male interviewee explains how this strategy results in stress:

In my circles and among the Romanies I spend time with, do note that it's a small per centage of Romanies, everybody suffers from extra stress - more than normal people. You can tell because they are a little more impulsive, and a bit fierier. They are stressed, and I notice it with my own people more often than with others. We suffer more from it.

The interviewee distinguishes between 'normal people' (in this context non-Romanies - gajos - who can be both the general population as well as other minority groups) and Romanies. He considers Romanies to be 'impulsive' and 'fiery', which could be positive words, although, conversely, their fieriness and impulsivity is actually considered to be a problem. The fieriness, impulsivity or stress can play a role in how interactions between people develop. Moreover, manifestations of stress can have consequences with health care staff as well.

Several interviewees depict incidents in the waiting room or confrontations in the reception area that, according to Goffman's (1972; 2000) dramaturgical perspective, require a cast of their own. In a conversation with a female interviewee about the background to these events, which have resulted from built-up irritation, the interviewee offers concrete, hands-on advice:

How should one react when it kicks off?

There is no point giving it back. Often you listen and take it all in, to the extent you can manage, 
but there are limits for what you can take; and that goes for health care as well, because there are those who take crap there too. Jesus, I have friends there so I know what it's like. You should be firm, but not raise your voice. You are firm in what you say, but try to finish it quickly because if you get worked up it's all over, all over. I have worked in the health care system too.

The advice she offers is to not 'get worked up' because then 'it's all over'. Furthermore, one should show a greater openness, especially when making first contact. With these thoughts, I conclude that it is probably the receptionists that are exposed, as they are 'the gatekeepers' and the link to the final goal: the doctors. However, there are examples that demonstrate that these incidents also create frustration when they actually meet the doctors. This frustration could possibly have grown gradually, but doctors and nurses are subject to the patients' general expectations that their job is, in any given situation, to reduce pain; help and restore weakened bodily functions; and, most importantly, deal with their suffering. They are expected to be polite, friendly, respectful and empathic, often all at once. Christina Maslach (1985) highlights that as a health care professional (or helper as she refers to it) you are constantly subject to high standards that are hard to live up to and impossible to maintain during an extended period of time. Maslach writes:

It is considered that helpers should always be warm-hearted and generous, resistant and polite, never curt, abrupt, unfriendly or cool. If the helper reaches this standard, it seldom raises applause or praise: 'There's nothing special about that, that's what's expected of you.' But if the expectations are not met, the critique will be hard. (Maslach 1985, p. 33)

\section{The Complexity of Trust}

The experience of discrimination has been highlighted through narratives from Romanies interacting with the health care system. I would like to stress that experiences of discrimination do not necessarily show a direct connection with lack of faith in the health care system itself. Both faith in and flaws in the health care system are context-bound complexities of problems that originate in the individual's need for help, experiences of serious disease, or other personal factors. However, this complexity results in the general wish to be seen, to be given time, and to be recognised as a human being - all universal wishes. Furthermore, advances in health care and medicine are often considered to be of a subordinate nature as it is human interaction that is rated.

I'm going to put it like this: here in Sweden, they have really, really good machines that can examine people. They have the best machines in the world to examine people. I have read about this, and Sweden comes in second, third or fourth place; but doctors, they don't have, and that's the problem. I can guarantee you one hundred per cent. If you come to my home country and you get sick, the doctor comes. He knows what is wrong with you without needing a machine. He takes [a stethoscope] and he knows straight away what is wrong with you. (Female interviewee)

Human interactions are held in high regard and to avoid conflicts it is important that professionals know how to explain things for the patient in a way that they understand. The ethnicity of the professionals is, according to this study, of lesser importance than their ability to communicate. Furthermore, communication is not necessarily about a mutual language, although this should not be underestimated. People have remarked that 'foreign' staff do not always understand what the patient is trying to say, for example, Danes "have an accent" and are hard to understand for some. One of the interviewees has made an active choice to stay in contact with a doctor who is originally from outside of Europe, and when asked why they chose this doctor, they replied:

Because he explained things so well to me. I understood everything. It really felt like he wanted me to understand.

\section{Another interviewee speculates:}


$[P]$ erhaps foreign doctors have experience in how it is to not understand. When he notices your facial expression [that one does not understand], he explains slower until you understand.

Therefore, doctors and nurses are expected to be able to listen, to explain and to communicate in a way that is understandable.

\section{Final Comments}

It should be pointed out that the sample of people that have participated in this study is limited. Further, individuals originating from different Roma communities and different parts of Europe have been allowed to voice their own personal perspectives. From this small sample of people, no general conclusions can be made. However, according to the participating Romanies, the general picture is that they would not consider themselves to be better served by health care staff with an increased knowledge of their culture. On the other hand, this is not conclusive of whether an increased knowledge about culturally specific issues actually would generally make things easier in the health care system. The understanding from health care professionals and other parts of society regarding issues such as family attendance around a sick person (which can result in larger gatherings) is certainly necessary. These are, however, isolated issues that do not contradict the general idea that cultural competency within the health care system is subordinate to a general understanding of the individual's problems, which can also include the patient's family.

The wishes from the Romanies I have been in contact with could be summarised in one word: respect - respect for them as a human beings, and respect for the medical problem that has led them to the health care system. According to the interviewed Romanies in this study, there is a further need for investment in health care. However, the focus should not be on health care staff developing knowledge about Romany culture, but, instead, on the Romanies' desire for an improved sensitivity towards individual preferences and needs as they are communicated. While information about Romanies and other groups in society can increase sensitivity towards people's conditions, it cannot give a prescribed description of how to interact with them in health care. Instead, what is required is an all-embracing respect and sensibility for the individual, the problems he or she expresses, and his or her need for care in order to reduce the experience of discrimination and generate the confidence that forms the health care system's ethic of trust.

\section{References}

Baumann, Gerd (1999). The Multicultural Riddle: Rethinking National, Ethnic and Religious Identities. London: Routledge.

Baumann, Gerd (2008). Contesting Culture: Discourses of Ethnicity in Multi-ethnic London. Cambridge: Cambridge University Press.

Berkowitz, Leonard (1974). Socialpsykologi. Stockholm: Bokförlaget Aldus.

Björk Brämberg, Elisabeth (2008). Att Vara Invandrare och Patient i Sverige. Växjö University Press.

Blais, C., Jack, R. E., Scheepers, C., Fiset, D., Caldara, R. (2008). Culture Shapes How We Look at Faces.

[Online: Open access article]. (Retrieved 20 August 2008). (URL: www.plosone.org).

Council of Europe (2003). Breaking the Barriers: Romani Women and Access to Public Health. European Agency

for Fundamental Rights (FRA): http://fra.europa.eu.

Davies, A., Basten, A., Frattini, C. (2006). Migration: A Social Determinant of the Health of Migrants. [Online]. (Retrieved July 2012). (URL: http://ec.europa.eu/ewsi/UDRW/images/items/docl_9914_392596992.pdf.)

DS (Departementsserien) (1997) 49 Romer i Sverige: Tillsammans i Förändring. Regeringskansliet:

Inrikesdepartementet.

Douglas, Mary (2004). Renhet Och Fara. En Analys av Begreppen Orenande och Tabu. Nora: Nya Doxa.

Dunbar, Robert (2006). Historien om Människan (The Human Story: A New History of Mankind's Evolution).

Ludvika: Dualis förlag.

Fast, Julius (1970). Kroppsspråket. Stockholm: Forum förlag.

Fraser, Nancy (2003). Den Radikala Fantasin: Mellan Omfördelning och Erkännade. Göteborg: Daidalos förlag. 
Fonseca, Maria Lucinda and Malheiros, Jorge. red. (2005). Social Integration and Mobility: Education, Housing and Health. IMISCOE Cluster B5, State of the Art Report: University of Lisbon.

Giddens, Anthony (1997). Modernitet och Självidentitet: Självet och Samhället I Den Senmoderna Epoken.

Stockholm: Bokförlaget Daidalos.

Gladwell, Malcolm (2006). Blink: Den Intuitiva Intelligensen. Stockholm: Prisma förlag.

Goffman, Erving (1972). Stigma: Den Avvikandes Roll och Identitet. Göteborg: Prisma förlag.

Goffman, Erving (2000). Jaget och Maskerna: En Studie i Vardagslivets Dramatik. Stockholm: Bokförlaget

Prisma.

Graham, H. ed. (2000). Understanding Health Inequalities. Buckingham: Open University Press.

Hays, D. (2008). Assessing Multicultural Competence in Counselor Trainees: A Review of Instrumentation and Future Directions. Journal of Counseling and Development. 86, pp. 95-101. In: Purdie, Nola, Dudgeon, Pat and Walker, Roz. eds. (2010). Working Together: Aboriginal and Torres Strait Islander Mental Health and Wellbeing Principles and Practice. Australian Government, Department of Health and Ageing.

Heidegren, Carl-Göran (2009). Erkännande. Malmö: Liber förlag.

Hofstede, G. (2001). Culture's Consequences: Comparing Values, Behaviors, Institutions, and Organizations

Across Nations. Thousand Oaks, California: Sage Publications, Inc.

Jenkins, Richard (2008). Social Identity. Routledge: London and New York

Kamali, Masoud (2002). Kulturkompetens I Socialt Arbete. Om Socialarbetarens och Klientens Kulturella

Bakgrund. Stockholm: Carlssons förlag.

Illman, Ruth and Nynäs, Peter (2005). Kultur, Människa, Möte: Ett Humanistiskt Perspektiv. Lund:

Studentlitteratur.

Kärfve, Eva (2010). Det Moraliska Spelet. Stehag: Symposion.

Leiniger, M. M. and Mcfarland, M.R. red. (2002). Culture Care Diversity and Universality. A Worldwide Nursing Theory. Sudbury, Massachusetts: Jones and Barlett publishers.

Lill, Linda (2007). Att Göra Etnicitet - Inom Äldreomsorgen. Odontologiska fakulteten och Internationella Migration och Etniska Relationer (IMER), Arbetslivsinstitutet Syd: Malmö högskola.

Mac Andrew, Francis T. (1986). A Cross-Cultural Study of Recognition Thresholds for Facial Expressions of Emotion. Journal of Cross-Cultural Psychology. 17, 2, pp. 211-224.

Madsen, K.B. (1970). Allmän Psykologi. Stockholm: Esselte studium.

Maslach, Christina (1985). Utbränd. Stockholm: Natur och Kultur.

Mead, George Herbert (1976). Medvetandet, Jaget och Samhället Från Sociabehavioristisk Ståndpunkt. Lund:

Argos förlag.

Mehrabian, Albert (2007). Nonverbal Communication. US: Transaction Publishers.

Morgan, Gareth (1997). Images of Organization. London, New Dehli: Sage Publications.

Områdesfakta (2008). Malmö stad.

Outhwaite, William and Bottomere, Tom (1994). Social Thought. Oxford: Blackwell Publishers.

Popoola, Margareta and Söderman, Emma (2010). Andras Ramar, Våra Villkor. Majoritetssamhället och

Romska Minoriteter I Förändring. Kavarengo Parancimo - Pala Sos Ame, Las Ame. OTem Taj O Remengo

Minoriteto Ande Parujimo. Malmö högskola: Enheten för kompetensutveckling och utvärdering i samarbete med IMER.

Putnam, Robert D. (2006). Den Ensamme Bowlaren. Stockholm: SNS förlag.

Ramirez, José Luis Den (2001). Mänskliga Existensens Grund - En Undersökning Om Tillitens Fenomenologi I. In: Aronsson, Gunnar \& Karlsson, Jan C.H. red. (2001) Tillitens Ansikten. Lund: Studentlitteratur.

Roe, Joe (2010). A Cultural and Spiritual Strengthening Model. In: Purdie, Nola., Dudgeon, Pat and Walker, Roz. eds. (2010). Working Together: Aboriginal and Torres Strait Islander Mental Health and Wellbeing Principles and Practice. Australian Government. Department of Health and Ageing.

Romani Glinda (2009). Romska Pass. Björklund: Bengt O.

Rorty, Richard (1992). Kontingens, Ironi og Solidaritet. Århus Forskningsfond.

Roth, Hans Ingvar (2008). Diskriminering. SNS förlag: Pocketbiblioteket nr 35.

Scheff, Thomas J. (1994). Microsociology: Discourse, Emotion, and Social Structure. Chicago / New York:

Chicago University Press.

Schölin, Tobias (2007). Etnisk Mångfald Som Organisationsidé. Chefs Och Personalpraktiker I Äldreomsorgen.

Malmö högskola: IMER och Fakulteten Hälsa och samhälle.

SFS (1982). 763 Hälso-och Sukvårdslagen. Svensk författningssamling.

SFS (2008). 567 Diskrimineringslagen. Svensk författningssamling.

SOS (2009). Migration och Hälsa i Socialstyrelsens. Folkhälsorapport 2009. 
SFHI (2005). Särbehandlad och Kränkt: En Rapport om Sambandet Mellan Diskriminering och Hälsa. Stockholm: Statens folkhälsoinstitut R 2005:49.

SFHI (2010). Hur Mår Sveriges Nationella Minoriteter? Stockholm: Statens folkhälsoinstitut delrapport 201001-15.

Smith, Ronald E. (1993). Psychology: University of Washington. NY/ San Fransisco / Los Angeles: West Publishing Co.

Söderman, Emma i samarbete med Ström, Britta (2008). Romers Situation I Malmö. En Rapport Om Malmös Minoritetspolitik Utifrån Romernas Perspektiv. Malmö stadskontor: Avdelningen för Integration och arbetsmarknad.

Taylor, Charles (1994). Det Mångkulturella Samhället och Erkännandets Politik. Göteborg: Daidalos. 